\title{
FEDERAL FACILITY COMPLIANCE AGREEMENT STACK ISOLATION PROJECT FUNCTIONS AND REQUIREMENTS
}

R. K. Tranbarger

Parsons for CH2M HILL Hanford Group, Inc.

Richland, WA 99352

U.S. Department of Energy Contract DE-AC27-99RL14047

\author{
EDTECN 721205-RO UC: \\ Cost Center: \\ Charge Code: \\ B\&R Code: \\ Total Pages: 25
}

Key Words: FFCA, DCRT, 244-A, 244-BX, 244-S, 244-TX, Stack, Ventilation, Isolation, Functions, Requirements, Passive Breather Filters

Abstract: This document delineates the functions and requirements for the FFCA Stack Isolation Project for the 244-A, 244-BX, 244-S, and 244-TX DCRTs. The isolation of each ventilation system and stack includes the elecrical, instrumentation, and mechanical isolation of the ventilation system and the installation of primary and annulus breather filters to provide passive ventilation to meet the FFCA requirements.

TRADEMARK DISCLAIMER. Reference herein to any specific commercial product, process, or service by trade name, trademark, manufacturer, or otherwise, does not necessarily constitute or imply its endorsement, recommendation, or favoring by the United States Government or any agency thereof or its contractors or subcontractors.

Printed in the United States of America. To obtain copies of this document, contact: Document Control Services, P.O. Box 950, Mailstop H6-08, Richland WA 99352, Phone (509) 372-2420; Fax (509) 376-4989.
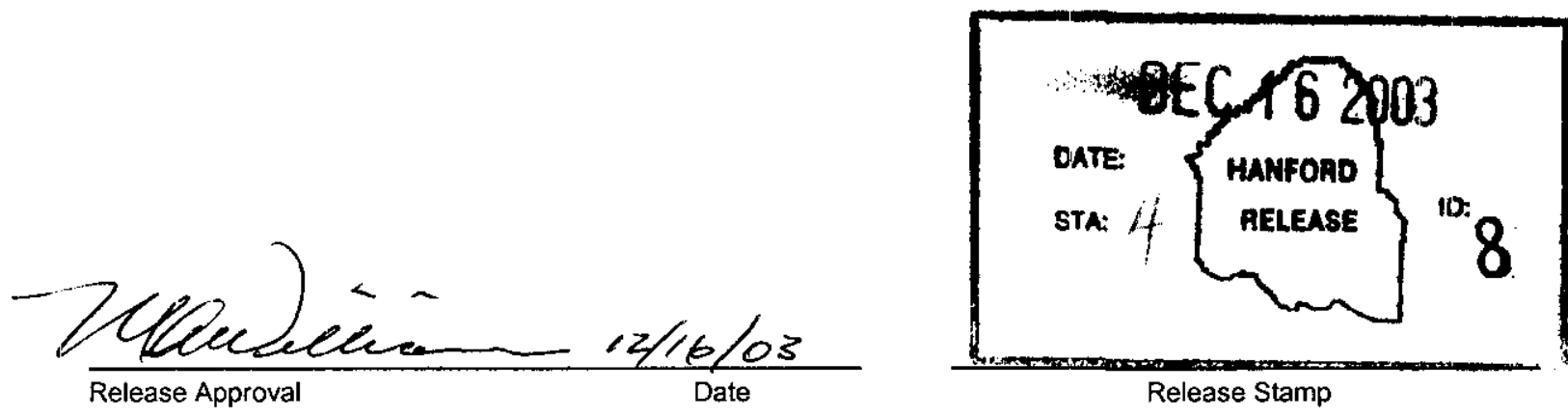

Release Stamp

\section{Approved For Public Release}


RECORD OF REVISION

(1) Document Number RPP-11829

Page 1

(2) Title

FEDERAL FACILITY COMPLIANCE AGREEMENT STACK ISOLATION PROJECT FUNCTIONS AND REQUIREMENTS

Change Control Record

(3) Revision

RS 1
(4) Description of Change - Replace, Add, and Delete Pages

(7)

Initially release February 21, 2003 on EDT-630539

Revised to update to DSA, current project

functions and requirements, reference documents, etc. per ECN-721205, Rev. 0
Authorized for Release

\begin{tabular}{|l|ll}
\hline (5) Cog. Engr. & (6) Cog. Mgr. & Date \\
\hline
\end{tabular}

T. Laney

D.H. Shuford

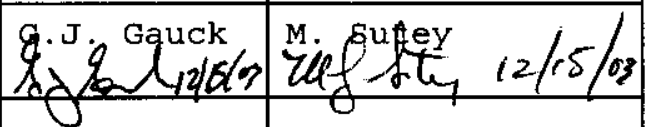

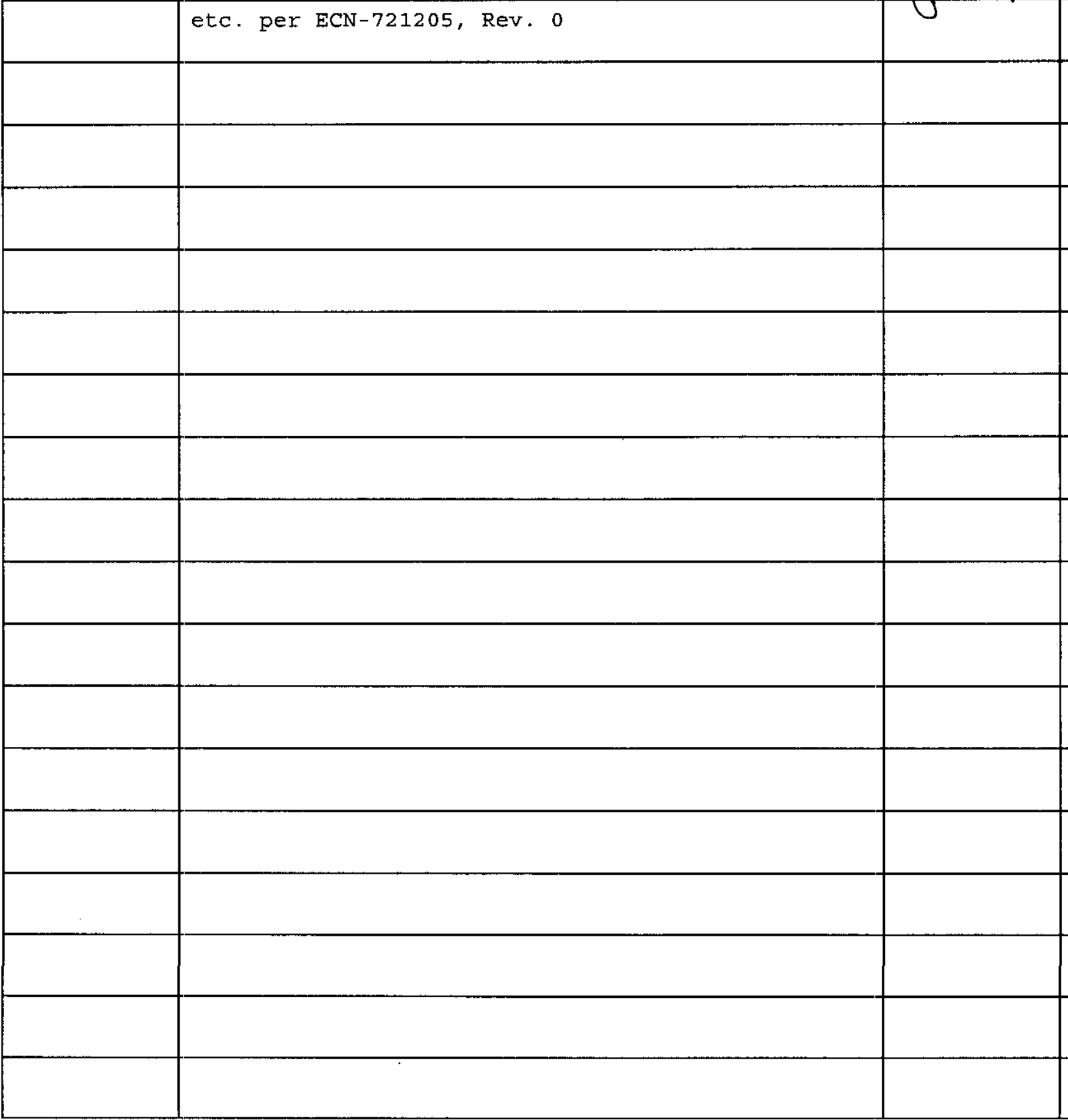




\section{FEDERAL FACILITY COMPLIANCE AGREEMENT}

\section{STACK ISOLATION PROJECT FUNCTIONS AND REQUIREMENTS}

December 2003

\section{CH2MHILL \\ Hanford Group, Inc.}

CH2M HILL HANFORD GROUP, INC.

P.O. Box 1500

Richland, WA 99352 


\section{Contents}

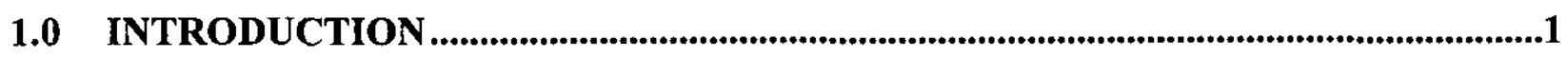

1.1 Scope

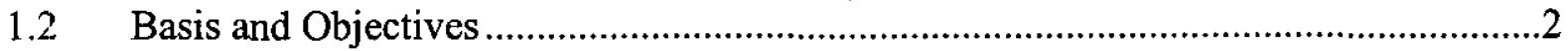

1.3 Safety Classifications ........................................................................................

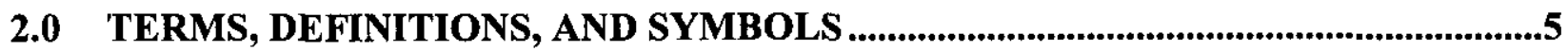

3.0 APPLICABLE DOCUMENTS AND INFORMATION_..................................................7

3.1 Applicable Hanford Standard Design Criteria and Practices........................................

3.2 Applicable Consensus Codes and Standards .............................................................

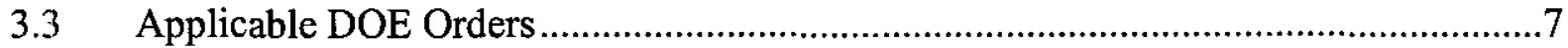

3.4 Applicable Government Regulations .......................................................................

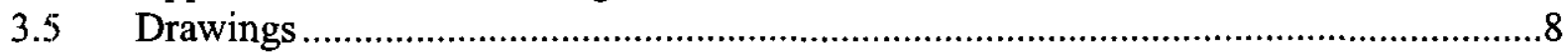

3.5.1 244-A (296-A-25) Stack Isolation Project Drawings .................................................. 8

3.5.2 296-B-28 Stack Isolation Project Drawings .............................................................

3.5.3 296-S-22 Stack Isolation Project Drawings ...............................................................

3.5.4 296-T-18 Stack Isolation Project Drawings .........................................................10

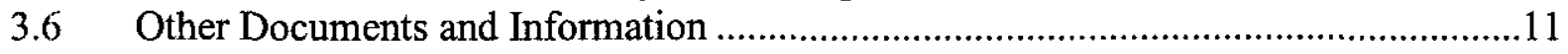

4.0 FUNCTIONS AND REQUIREMENTS..........................................................................12

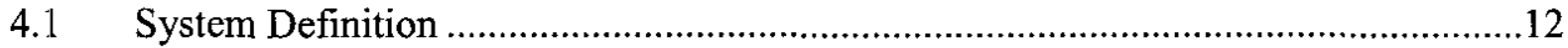

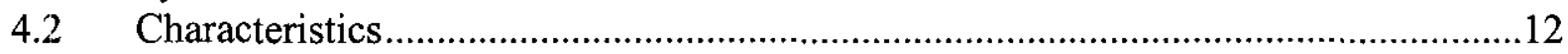

4.3 Technical Design Requirements, Constraints, and Criteria ....................................13

4.3.1 296-A-25 and 296-S-22 Stack Isolation Projects ......................................................13

4.3.2 296-B-28 and 296-T-18 Stack Isolation Projects ...................................................15

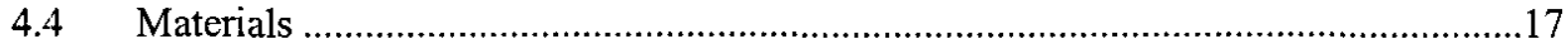

4.5 Architectural/Civil Engineering and Site Work...................................................18

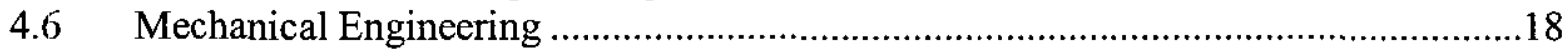

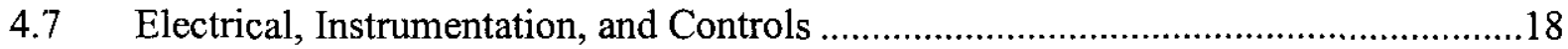

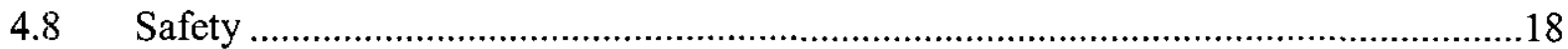

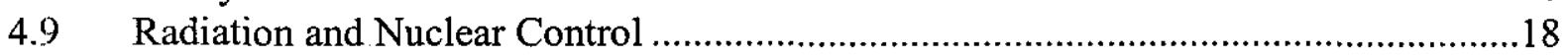

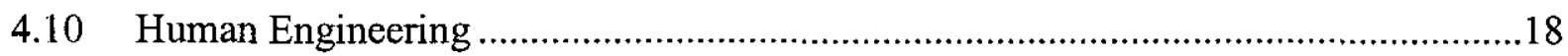

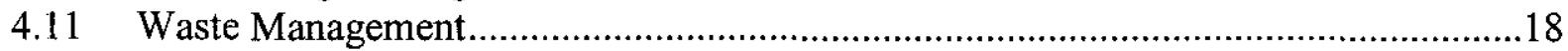

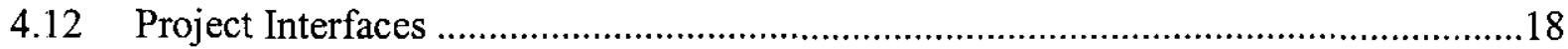

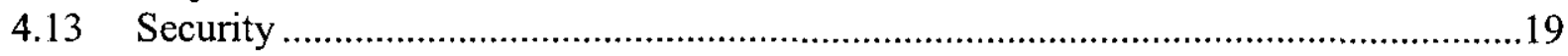

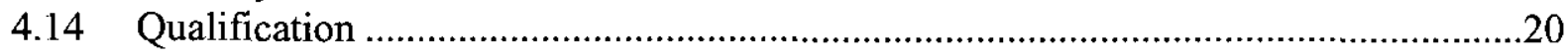

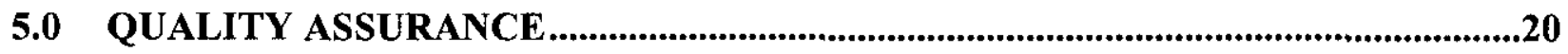

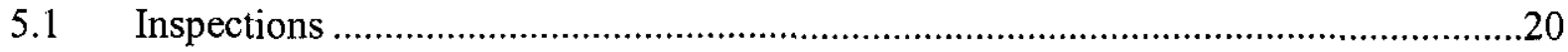

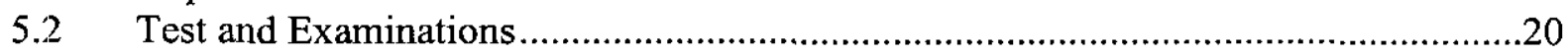

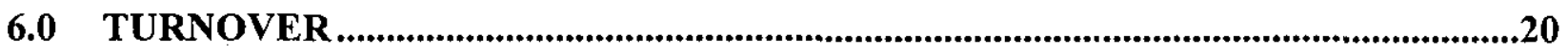




\section{List of Tables and Figures}

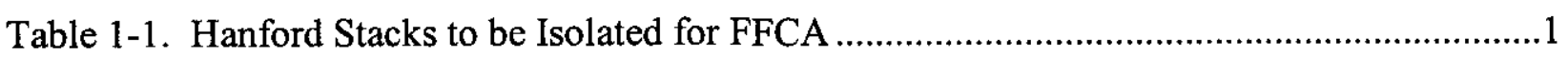

Table 3-1. 296-A-25 Stack Isolation Project Drawings.................................................................

Table 3-2. 296-B-28 Stack Isolation Project Drawings ..................................................................

Table 3-3. 296-S-22 Stack Isolation Project Drawings ....................................................................

Table 3-4. 296-T-18 Stack Isolation Project Drawings .................................................................10

Figure 1-1. Schematic Diagram for the FFCA Stack Isolation Project .........................................4

Figure 4-1. Project Organization and Standards Interface $\ldots . . \ldots \ldots \ldots \ldots \ldots \ldots \ldots \ldots \ldots \ldots \ldots \ldots \ldots \ldots \ldots \ldots \ldots \ldots \ldots \ldots \ldots . . .19$ 


\subsection{INTRODUCTION}

In 1994, the U.S. Department of Energy (DOE), Richland Operations Office, and the U.S. Environmental Protection Agency (EPA), Region 10, signed a National Emissions Standards for Hazardous Air Pollutants Federal Facility Compliance Agreement (Letter 94RPS-128, J. D. Wagoner to G. A. Emison, dated February 2, 1994), referred to as the FFCA. The FFCA was entered into by the parties to bring the Hanford Site into compliance with the Clean Air Act (CAA), as amended, 42 United States Code (U.S.C.) 7401 et seq., and its implementing regulations at Title 40, Code of Federal Regulations (CFR) Part 61, National Emission Standards For Hazardous Air Pollutants (NESHAPs). The FFCA requires that all Hanford Site stacks be compliant with the NESHAPs by December 31, 2005.

The NESHAPs require that each ventilation stack be assessed for its potential to emit radionuclides (except radon). Based on the required assessment, upgraded emission monitoring systems must be provided for those stacks that could exceed an emission threshold of 0.1 mrem per year. Stacks that have the potential to exceed emissions of $0.1 \mathrm{mrem}$ per year are designated stacks or "major stacks." Stacks with emissions less than 0.1 mrem per year are non-designated or "minor stacks."

Assessments (e.g., HNF-SD-WM-EMP-031, Tank Farm Stack NESHAP Designation Determinations) determined that six major ventilation exhaust stacks operated and/or maintained by $\mathrm{CH} 2 \mathrm{M}$ HILL do not meet the emission monitoring standards. The six stacks, their associated facility/structure, and the responsible CH2M HILL project for their isolation are listed in Table 1-1. Table 1-1 also lists the State of Washington Department of Health (WDOH) approval letter number (AIR), Notice of Construction (NOC) identification number (ID), and Emission Unit ID associated with the closure of these stacks.

Table 1-1. Hanford Stacks to be Isolated for FFCA

\begin{tabular}{|l|c|c|c|c|c|}
\hline Stack & $\begin{array}{c}\text { Approval } \\
\text { Number } \\
\text { (AIR) }\end{array}$ & $\begin{array}{c}\text { NOC } \\
\text { ID }\end{array}$ & $\begin{array}{c}\text { Emission } \\
\text { Unit ID }\end{array}$ & $\begin{array}{c}\text { Facility/ } \\
\text { Structure }\end{array}$ & $\begin{array}{c}\text { Responsible CH2M Hill } \\
\text { Project }\end{array}$ \\
\hline 296-A-25 & $03-611$ & 578 & 738 & 244-A Catch Tank & DST Life Extension Projects \\
\hline $296-$ B-28 & $03-611$ & 578 & 740 & 244-BX DCRT & DST Life Extension Projects \\
\hline $296-$ S-22 & $03-611$ & 578 & 742 & 244-S DCRT & DST Life Extension Projects \\
\hline $296-T-18$ & $03-611$ & 578 & 744 & 244-TX DCRT & DST Life Extension Projects \\
\hline 296-C-05 & $02-1255$ & 548 & 498 & 244-CR Vault & Not Currently Identified \\
\hline 296-P-16 & Not Assigned & 539 & 712 & 241-C-106 SST & Corrective Maintenance \\
\hline \\
1. The Tank Farms Documented Safety Analysis (DSA), RPP-13033, implemented October 2003, recatergorized 244-A from a DCRT to a \\
Catch Tank. The FFCA refers to 244-A as a DCRT. \\
DCRT = Double-Contained Receiver Tank \\
DST = Double-Shell Tank \\
SST = Single-Shell Tank
\end{tabular}

To make the stacks compliant, Project W-420, Stack Monitoring System Upgrades, was initiated to replace the existing stack record sampler and continuous air monitor (CAM) at each stack with a generic effluent monitoring system (GEMS). The total cost to install the six GEMS was estimated at greater than $\$ 5.0$ million. 
Because of the high cost to install the GEMS, and because the facilities are planned to be deactivated or closed (i.e., pumpable waste removed and process lines isolated) before December 31, 2005, other alternatives to meet the FFCA were evaluated. RPP-8351, W-420 Stack Monitoring System Upgrades Engineering Task Plan, documented this alternative evaluation, and concluded that, to comply with the FFCA, the best path forward is to complete the mission of the associated tanks and isolate the stacks.

In November 2001, ORP Letter 01-AMPD-117, Project W-420 Stack Monitoring Upgrades, Recommended Path Forward, requested CH2M HILL to:

- Cancel Project W-420, and

- Plan and execute the recommended path forward to isolate and close the exhaust stacks to meet the FFCA by December 31, 2005.

The 296-A-25 stack isolation project was completed in calendar year 2003. The 296-B-28 stack isolation project is scheduled for completion in fiscal year (FY) 2004. The 296-S-22 and 296-T18 stack isolation projects are scheduled for completion in FY 2005.

\subsection{Scope}

This F\&R document defines the requirements and criteria for the isolation of the 296-A-25 (completed), 296-B-28, 296-S-22, and 296-T-18 ventilation stacks currently operated and/or maintained by CH2M HILL, as identified in Table 1-1. The F\&Rs for the 296-P-16 and 296-C05 stacks are not considered herein; the 296-P-16 stack was deactivated and isolated in May 2003. The deactivation/isolation of the 296-C-05 stack is not funded or scheduled at this time (reference Problem Evaluation Request PER-2003-4212). The F\&Rs for the isolation of 296-A25 have been updated and retained to document the final $F \& R s$ for that project.

This F\&R document does not identify the functions and requirements for interim stabilization or isolation of catch tanks or DCRTs.

\subsection{Basis and Objectives}

The basis for the FFCA Stack Isolation Project is ORP Letter 01-AMPD-117, which directed $\mathrm{CH} 2 \mathrm{M}$ HILL to plan and execute the recommended path forward to isolate and close the exhaust stacks to meet the FFCA by December 31, 2005.

The objective of the Stack Isolation Project is to deactivate and isolate the stack ventilation systems to meet the requirements of the FFCA. To support isolation of the stacks, passive breather filter systems will be installed on the receiver tank and tank annulus at each facility. Additional modifications will be made to the facilities and stacks based on recommendations from engineering and operations. Figure 1-1 is a schematic diagram for the FFCA Stack Isolation Project, and summarizes the design changes needed to fulfill the F\&Rs identified herein. 


\subsection{Safety Classifications}

The 244-A, 244-BX, 244-S, and 244-TX ventilation systems are all classified as General Service. However, the 244-BX, 244-S, and 244-TX purge air systems are classified as SafetySignificant per RPP-8792, Sub-System and Component Level Safety Equipment List for Tank Farm Safety Systems, Section 4.2, and RPP-13033, Tank Farms Documented Safety Analysis (DSA), Table 3.3.2.4.1-6. RPP-8792, states, "The safety function of the double-contained receiver tank (DCRT) purge air systems is to maintain the concentration of flammable gases from steady-state releases below the LFL in the DCRT headspace, thus decreasing the frequency of a flammable gas accident."

NOTE: The implementation of the Tank Farms Documented Safety Analysis (DSA), RPP13033 , in October 2003, recategorized 244-A from a DCRT to a catch tank, and in doing so downgraded the 244-A purge air system to General Service. The 244-A purge air was active during construction for the 244-A Stack Isolation Project in 2003.

The FFCA Stack Isolation Project will not deactivate the purge air systems. 

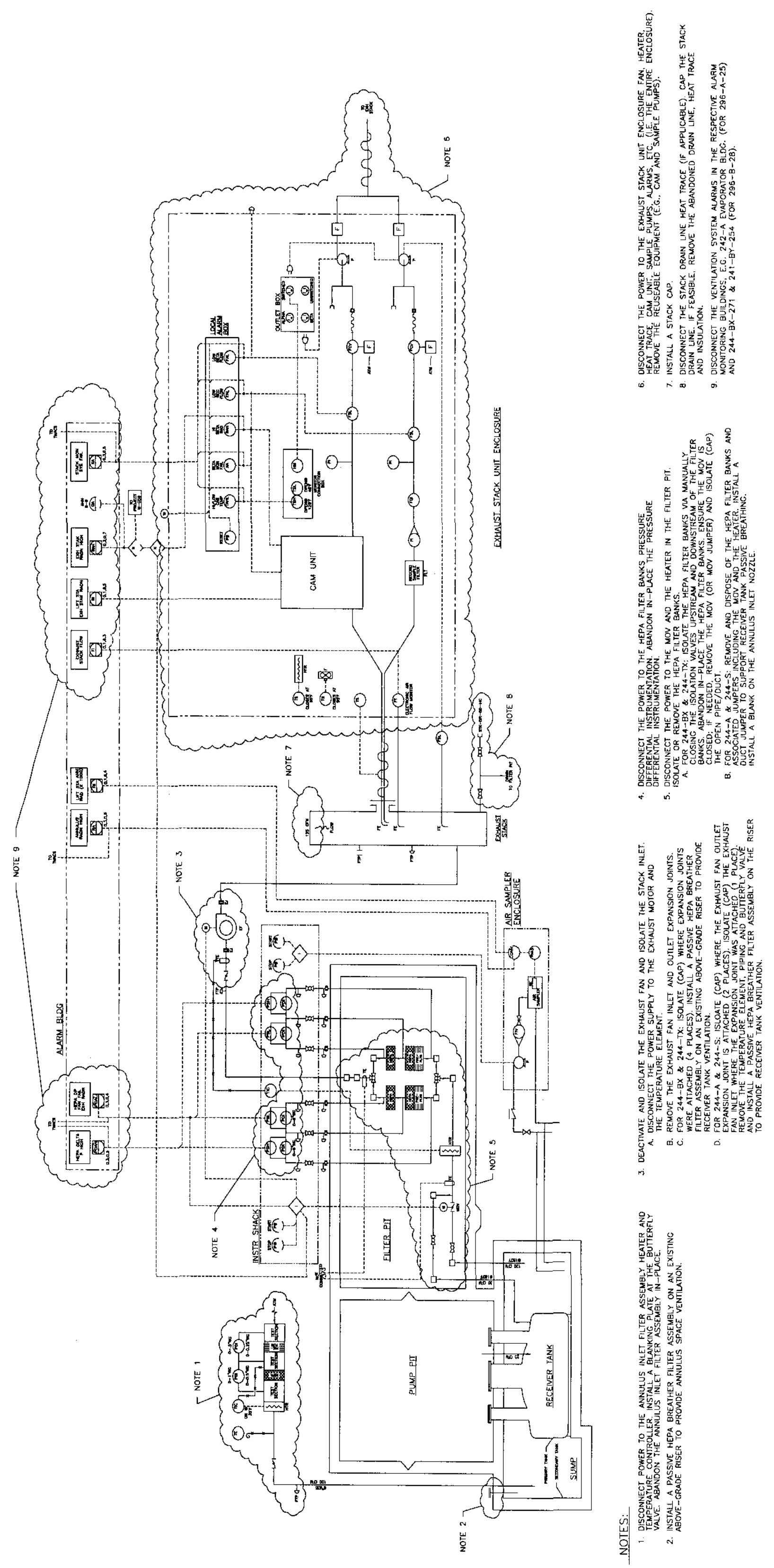


\subsection{TERMS, DEFINITIONS, AND SYMBOLS}

$\begin{array}{ll}\text { ALARA } & \text { As Low As Reasonably Achievable } \\ \text { ASME } & \text { American Society of Mechanical Engineers } \\ \text { CAA } & \text { Clean Air Act } \\ \text { CAM } & \text { Continuous Air Monitor } \\ \text { CFR } & \text { Code of Federal Regulations } \\ \text { CH2M Hill } & \text { CH2M Hill, Inc. } \\ \text { DCRT } & \text { Double-Contained Receiver Tank } \\ \text { DOE } & \text { Department of Energy } \\ \text { DSA } & \text { Documented Safety Analysis } \\ \text { DST } & \text { Double-Shell Tank } \\ \text { ECN } & \text { Engineering Change Notice } \\ \text { EPA } & \text { Environmental Protection Agency } \\ \text { F\&R } & \text { Functions and Requirements } \\ \text { FFCA } & \text { Federal Facility Compliance Agreement } \\ \text { FY } & \text { Fiscal Year } \\ \text { GEMS } & \text { Generic Effluent Monitoring System } \\ \text { HEPA } & \text { High Efficiency Particulate Air } \\ \text { HESP } & \text { Hanford Electrical Safety Program } \\ \text { ICD } & \text { Interface Control Document } \\ \text { ID } & \text { Identification } \\ \text { LFL } & \text { Lower Flammability Limit } \\ \text { MOV } & \text { Motor Operated Valve } \\ \text { NESHAPs } & \text { National Emissions Standards for Hazardous Air Pollutants } \\ \text { NEC } & \text { National Electrical Code } \\ \text { NFPA } & \text { National Fire Protection Association } \\ \text { NOC } & \text { Notice of Construction } \\ \text { ORP } & \text { Office of River Protection } \\ \text { PCM } & \text { Periodic Confirmatory Measurements } \\ \text { PFP } & \text { Plutonium Finishing Plant } \\ \text { P\&ID } & \text { Piping and Instrumentation Diagram } \\ \text { PTE } & \text { Potential to Emit } \\ \text { RCRA } & \text { Resource Conservation and Recovery Act } \\ \text { RPP } & \text { River Protection Project } \\ \text { SST } & \text { Single-Shell Tank } \\ \text { TSR } & \text { Technical Safety Requirement } \\ \text { USC } & \text { United States Code } \\ \end{array}$




\section{RPP-11829 REV. 1}

USQ Unreviewed Safety Question

WAC Washington Administrative Code

WDOH Washington Department of Health 
RPP-11829 REV. 1

\subsection{APPLICABLE DOCUMENTS AND INFORMATION}

The documents referenced in this Chapter are applicable to the design of the 296-A-25, 296-B28, 296-S-22, and 296-T-18 Stack Isolation Projects. Current revisions shall be used.

\subsection{Applicable Hanford Standard Design Criteria and Practices}

1. HNF-IP-0842, Volume 6, 1.7, Air Quality-Radioactive Emissions

2. HNF-IP-1266, Tank Farms Operations Administrative Controls

3. TFC-BSM-CP-CPR-C-03, Buyer's Technical Representative Process

4. TFC-BSM-CP-CPR-C-06, Procurement of Items (Materials)

5. TFC-BSM-CP-CPR-C-09, Supply Chain Process

6. TFC-BSM-CP-CPR-C-11, Acquisition Planning

7. TFC-BSM-FPM-MC-C-01, Material Receipt, Storage, Issuance, Return, and Excess Control

8. TFC-ENG-FACSUP-P-03, Tank Farm Facility Intrusion Prevention

9. TFC-ENG-STD-06, Design Loads for Tank Farm Facilities

10. TFC-ENG-STD-07, HEPA Filter Requirements

11. TFC-ESHQ-Q ADM-D-04, Quality Assurance Program Description Implementation Matrix

12. TFC-PLN-02, Quality Assurance Program Description

13. TFC-PLN-03, Engineering Program Management Plan

14. TFC-PRJ-PM-C-06, Operational Acceptance

\subsection{Applicable Consensus Codes and Standards}

1. ASME AG-1, Code on Nuclear Air and Gas Treatment, Sections AA, HA, SA, and TA

2. ASME B31.3, 1999, Process Piping, American Society of Mechanical Engineers, New York, New York.

3. ASME N509, Nuclear Power Plant Air Cleaning Units and Components

4. ASME N510, Testing of Nuclear Air Cleaning Units and Components

5. ASME NQA-1, Quality Assurance Requirements for Nuclear Facility Applications

6. NFPA 70, 1999, National Electrical Code (NEC), National Fire Protection Association, Quincy, Massachusetts

\subsection{Applicable DOE Orders}

The following DOE Orders apply to the extent they are invoked by applicable Standards/ Requirements Identification Documents (S/RIDS).

1. DOE O 430.1a, Life-Cycle Asset Management

2. DOE O 414.1A, Quality Assurance

3. DOE O 420.1A, Facility Safety

\subsection{Applicable Government Regulations}

1. WAC Chapter 173-401, Washington Administrative Code, Operating Permit Regulation

2. WAC Chapter 246-247, Washington Administrative Code; Radiation Protection - Air Emissions 
3. 10 CFR 830.120 , Quality Assurance

4. 40 CFR 61 Subpart H (61.93), National Emission Standards for Emissions for Radionuclides Other Than Radon From Department of Energy Facilities

5. 40 CFR 61.07, National Emission Standards for Hazardous Air Pollutants, Application for Approval of Construction or Modification.

\subsection{Drawings}

The drawings applicable to, and necessary for design development of each stack isolation project are listed in the following subsections.

\subsubsection{4-A (296-A-25) Stack Isolation Project Drawings}

Table 3-1 lists the drawings that were generated or revised for the 296-A-25 Stack Isolation Project work scope performed in 2003.

Table 3-1. 296-A-25 Stack Isolation Project Drawings

\begin{tabular}{|c|l|}
\hline Drawing Number & \multicolumn{1}{|c|}{ Title } \\
\hline H-14-105385-1, -2, -3, \& -4 & Piping Passive Air Breather 4" and 6" Assembly \\
\hline H-14-105386-1 \& -2 & Jumper Assembly Filter Pit 244-A 244A-FP-C-F1 \\
\hline H-14-020104-1 \& -2 & Ventilation Tank Primary (VTP) O\&M System P\&ID \\
\hline H-14-020204 & Ventilation Tank Annulus (VTA) O\&M System P\&ID \\
\hline H-14-030004-1 & Electrical (EDS) One-Line Diagram \\
\hline H-14-030004-2 & Electrical (EDS) Panelboard Schedule Index \\
\hline H-14-030004-3 \& -4 & Electrical (EDS) Panelboard Schedule \\
\hline H-2-38209 & Electrical Control Diagrams (partially superceded by H-14-030004) \\
\hline H-2-38210 & Electrical Plan \& Details \\
\hline H-2-38211 & Electrical Control Diagrams \\
\hline H-2-38214 & Ventilation Air Flow and Control Diagram Schedules \\
\hline H-2-38215 & Ventilation Plan \& Details \\
\hline H-2-38233 & Jumper Arrangement Lift Station \\
\hline H-2-95298-2 & 296-A-25 Stack Monitor Wiring Diagram \\
\hline H-2-99059-1 \& -7 & Instm Interconnection Diagram \\
\hline H-2-99085-7, -8, \& -16 & Electrical Elementary Diagrams \\
\hline
\end{tabular}

\subsubsection{6-B-28 Stack Isolation Project Drawings}

The drawings listed in Table 3-2 were compiled for the 296-B-28 Stack Isolation Project, and will be revised as appropriate during the design phase of the project.

Table 3-2. 296-B-28 Stack Isolation Project Drawings

\begin{tabular}{|c|c|}
\hline Drawing Number & \multicolumn{1}{c|}{ Title } \\
\hline H-14-020119-1 \& -2 & Ventilation Tank Primary (VTP) O\&M System P\&ID \\
\hline H-14-020219 & Ventilation Tank Annulus (VTA) O\&M System P\&ID \\
\hline
\end{tabular}




\begin{tabular}{|c|l|}
\hline H-14-020519-1 & Waste Storage Tank Annulus System (WSTA) O\&M System P\&ID \\
\hline H-14-020619-1 & Waste Storage Tank System (WST) O\&M System P\&ID \\
\hline H-2-030019-1 & Electrical (EDS) One Line Diagram \\
\hline H-2-030019-2 & Electrical (EDS) Panelboard Schedule \\
\hline H-2-73802-1 & Instrumentation Panel ARRANG. System 1, 2, 3, \& 5 \\
\hline H-2-73803-1 & Instrumentation Rear of Panel Wiring System NO. 2 \\
\hline H-2-73809-1 & Instrumentation Exhaust Unit ENCL ASSY-SYS 2 \& 3 \\
\hline H-2-73810-1 & Instrumentation Annulus Unit ENCl Assembly \\
\hline H-2-73811-2 & Instrumentation Interconnection Diagram \\
\hline H-2-73815-2 & Instrumentation Annunciator ARRGT and Wiring \\
\hline H-2-73815-3 & Instrumentation Annunciator Legend \\
\hline H-2-73819-1 & Electrical Elementary Diagram System NO. 2 \\
\hline H-2-73819-2 & Electrical Elementary Diagram System NO. 2 \\
\hline H-2-73820-1 & Electrical One Line \& ELEM Diagram System NO. 3 \\
\hline H-2-73820-2 & Electrical One Line \& ELEM Diagram System NO. 3 \\
\hline H-2-73822-1 & Electrical Leak DET, HT Trace \& ANN Elementary Diagram System 2 \\
\hline H-2-73822-2 & Electrical Leak DET, HT Trace \& ANN Elementary Diagram System 2 \\
\hline H-2-73823-1 & Electrical Leak DET, HT Trace \& ANN Elementary Diagram System 3 \\
\hline H-2-73830-1 & Electrical INSTR BLDG 244-BX, -TX System NOS. 1 \& 2 \\
\hline H-2-73835-1 & ELEC/Instrumentation Wire Run List System 2 \\
\hline H-2-73838-1 & HVAC Air Flow and Control Diagram and Schedule \\
\hline H-2-73838-2 & HVAC Air Flow and Control Diagram and Schedule \\
\hline H-2-90718 & Piping Air Filter Installation Atmospheric Breathing \\
\hline
\end{tabular}

\subsubsection{6-S-22 Stack Isolation Project Drawings}

The drawings listed in Table 3-3 were compiled for the 296-S-22 Stack Isolation Project design, and will be revised as appropriate during the design phase of the project.

Table 3-3. 296-S-22 Stack Isolation Project Drawings

\begin{tabular}{|c|l|}
\hline Drawing Number & \multicolumn{1}{|c|}{ Title } \\
\hline H-14-020000 & Tank Farms System P \& ID Structure Legend \\
\hline H-14-020153 & Ventilation Tank Primary (VTP) O\&M System P\&ID \\
\hline H-14-020253 & Ventilation Tank Annulus (VTA) O\&M System P\&ID \\
\hline H-14-020553 & Waste Storage Tank Annulus System (WSTA) O\&M System P\&ID \\
\hline H-14-020653 & Waste Storage Tank System (WST) O\&M System P\&ID \\
\hline H-14-020853 & Waste Transfer System (WT) O\&M System P\&ID \\
\hline H-14-021853 & Raw Water System (RW) O\&M System P\&ID \\
\hline H-14-030053 & Electrical Diagram and Panelboard Schedules \\
\hline H-2-34965 & Leak Detector Assembly Typical Details \\
\hline H-2-46436 & Electrical Annunciator Diagrams \\
\hline H-2-46786 & Elec/Instm/Interconnection Diagram/Efd \\
\hline H-2-46302 & Instrumentation Panels A, B, and C Arrangements (242-S). \\
\hline H-2-46304 & Instrumentation Rear Panel Wiring Panels A, B, and C (242-S). \\
\hline H-2-46789 & Elec / Instr Plans, El, Det \& Elem Diagrams \\
\hline H-2-46790 & Elect/Instrm Panel Arrangement Wiring and Detail (242-S). \\
\hline H-2-71040 & Drawing List \\
\hline
\end{tabular}


Table 3-3. 296-S-22 Stack Isolation Project Drawings

\begin{tabular}{|c|l|}
\hline Drawing Number & \multicolumn{1}{|c|}{ Title } \\
\hline H-2-71047 & Ventilation Air Flow And Control Diag And Sched \\
\hline H-2-71048 & Ventilation Plan \& Details \\
\hline H-2-71091 & Electrical Control \& Elem Diagrams \\
\hline H-2-71093 & Electrical Wire Run List and Conduit Schedule (244-S) \\
\hline
\end{tabular}

\subsubsection{6-T-18 Stack Isolation Project Drawings}

The drawings listed in Table 3-4 were compiled for the 296-T-18 Stack Isolation Project design, and will be revised as appropriate during the design phase of the project.

Table 3-4. 296-T-18 Stack Isolation Project Drawings

\begin{tabular}{|c|l|}
\hline \multicolumn{1}{|c|}{ Drawing Number } & \multicolumn{1}{|c|}{ Title } \\
\hline H-14-020141 & Ventilation Tank Primary (VTP) O\&M System P\&ID \\
\hline H-14-020241 & Ventilation Tank Annulus (VTA) O\&M System P\&ID \\
\hline H-14-020341 & Service \& Instrument Air (SA/IA) System O\&M System P\&ID \\
\hline H-14-020541 & Waste Storage Tank Annulus System (WSTA) O\&M System P\&ID \\
\hline H-14-020641 & Waste Storage Tank System (WST) O\&M SYSTEM P\&ID \\
\hline H-14-020841 & Waste Transfer System (WT) O\&M System P\&ID \\
\hline H-14-021841 & Raw Water System (RW) O\&M System P\&ID \\
\hline H-2-73185 & Piping Waste Tank Isolation 241-S-106 \\
\hline H-2-73780 & Drawing List \\
\hline H-14-020141 & Ventilation Tank Primary (VTP) O\&M System P\&ID \\
\hline H-14-020241 & Ventilation Tank Annulus (VTA) O\&M System P\&ID \\
\hline H-14-020341 & Service \& Instrument Air (SA/IA) System O\&M System P\&ID \\
\hline H-14-020541 & Waste Storage Tank Annulus System (WSTA) O\&M System P\&ID \\
\hline H-14-020641 & Waste Storage Tank System (WST) O\&M System P\&ID \\
\hline H-14-020841 & Waste Transfer System (WT) O\&M System P\&ID \\
\hline H-14-021841 & Raw Water System (RW) O\&M System P\&ID \\
\hline H-2-73800 & Engineering Flow Diagram System No. 5 \\
\hline H-2-73805 & Instrumentation Instrument Building Arrangement \& Det \\
\hline H-2-73818 & Electrical One-Line \& Elem Diag System No. 1 \\
\hline H-2-73821 & Electrical Leak Det, Ht Trace \& Ann Elem Diag - System 1 \\
\hline H-2-73830 & Electrical Instr Bldg 244-Bx, Tx System No. 1, 2 \\
\hline H-14-030036 & Electrical (EDS) One Line Diagram \\
\hline H-14-030041 & Electrical (EDS) One Line Diagram \\
\hline H-2-95393 & Manual Liquid Level Installation \\
\hline H-2-72187 & Instm Tk 101 \& 102 Tk Sludge Level, Liquid Level \& Liq Lvl Alarm Assy \& Det \\
\hline H-2-90718 & Piping Air Filter Installation Atmospheric Breathing \\
\hline H-2-73901 & Piping Plan And Details \\
\hline H-2-73802 & Instrumentation Panel Arrangement System No 1, 2, 3, \& 5 \\
\hline & \\
\hline
\end{tabular}




\section{RPP-11829 REV. 1}

\subsection{Other Documents and Information}

1. Letter 01-AMPD-117, Contract Number DE-AC27-99RL14047-Project W-420 Stack Monitoring Upgrades, Recommended Path Forward, J. S. O'Connor, ORP, to M.P. DeLozier (CHG), CHG-0104837, dated November 7, 2001.

2. Letter, J.D. Wagoner, RL, to G.A. Emison, EPA, Transmission of the National Emission Standards for Hazardous Air Pollutants Federal Facility Compliance Agreement, 94-RPS-128, dated February 2, 1994.

3. HNF-S-0552, Specification for Procurement of Nuclear Grade High Efficiency Particulate Air (HEPA) Filters.

4. HNF-SD-WM-EMP-031, Tank Farm Stack NESHAP Designation Determinations

5. HNF-4483, Rev. 0, Interface Control Document Between the Tank Farm System and the 222-S Laboratory, October 1999, Numatec Hanford Company, Richland, Washington.

6. HNF-4486, Rev. 0, Interface Control Document Between the Double-Shell Tanks (DST) and the Plutonium Finishing Plant (PFP), November 1999, Numatec Hanford Company, Richland, Washington.

7. HNF-5183, Tank Farm Radiological Control Manual.

8. RPP-8351, W-420 Stack Monitoring System Upgrades Engineering Task Plan.

9. RPP-8792, Rev. 5, Subsystem and Component Level Safety Equipment List for Tank Farms Safety Systems.

10. RPP-13033, Rev. 0, Tank Farms Documented Safety Analysis. 


\subsection{FUNCTIONS AND REQUIREMENTS}

\subsection{System Definition}

The primary purpose of the Stack Isolation Project is to ensure that the 296-A-25, 296-B-28, 296-S-22, and 296-T-18 ventilation stack systems are compliant with the NESHAPs in accordance with the FFCA and Hanford Site requirements. The clouds and notes in Figure 1-1, Schematic Diagram for the FFCA Stack Isolation Project, define the Stack Isolation Project system and show the physical interfaces. In general, the project can be defined in five categories:

1. Install a passive HEPA breather filter assembly on the receiver tank and annulus space;

2. Disconnect power to the exhaust fan, stack emissions monitoring equipment, HEPA filter bank monitoring and control instrumentation (e.g., differential pressure indicators), monitoring system alarms, and annulus inlet filter assembly;

3. Isolate and/or remove existing HEPA filter banks in the filter pit and install a duct jumper (as needed to support passive ventilation);

4. Isolate the exhaust fans, stacks and stack drains; and

5. Isolate the annulus inlet breather filter assembly.

Further description of the activities to be performed for each of these categories is provided in Section 4.3.

\subsection{Characteristics}

A passive HEPA filter "breather" system will be installed on the receiver tank to serve as the static vent for the purge air injected into the receiver tank and to provide for atmospheric breathing. The receiver tank HEPA filter will allow the gases to escape while collecting any airborne radioactive particulates. The injection of air into the 244-BX, 244-S, and 244-TX receiver tanks is required by the DSA (Section 4.4.2) to ensure that tank gases do not exceed $25 \%$ of the lower flammability limit (LFL).

A passive HEPA filter breather system on the annulus tank will provide for the exchange of ambient air with the annulus tank during atmospheric pressure fluctuations. The annulus tank HEPA filter will collect potential airborne radioactive particulates from the annulus space while allowing tank vapors to escape.

Exhauster fan, monitoring instrumentation, and alarm deactivation requires disconnecting the electrical power to the exhaust fan, the exhaust stack unit enclosure (CAMs, exhaust fans, exhaust stack instrumentation, sample pumps, heater, heat trace), the motor operated valve (MOV) and heater in the filter pit, HEPA filter banks monitoring instruments, and the annulus inlet filter.

In the 244-A and 244-S filter pits, the HEPA filter banks and associated jumpers in the filter pit will be removed and replaced with duct jumper to support passive breathing of the receiver tank. The annulus inlet nozzles will be closed and/or isolated to ensure cross-contamination between the receiver tank and annulus space cannot occur. 
In the 244-BX and 244-TX filter pits, the HEPA filter banks will be isolated and abandoned inplace. The MOV will be verified as closed to ensure cross-contamination between the receiver tank and annulus space cannot occur.

The exhaust fan and stack will be capped such that water, small debris, and insects cannot readily infiltrate. The stack drain will be plugged.

The annulus inlet filter ventilation pathway will be closed and isolated, and the assembly abandoned in-place.

\subsection{Technical Design Requirements, Constraints, and Criteria}

Because the 296-A-25 (244-A) and 296-S-22 (244-S) ventilation systems are nearly identical and the 296-B-28 (244-BX) and 296-T-18 (244-TX) ventilation systems are nearly identical, their respective requirements, constraints, and criteria are combined into section 4.3.1 and 4.3.2 respectively.

\subsubsection{6-A-25 and 296-S-22 Stack Isolation Projects}

The following subsections describe the requirements, constraints, and criteria for the 296-A25 (244-A) and 296-S-22 (244-S) Stack Isolation Projects. Note that the 296-A-25 stack was deactivated and isolated in calendar year 2003.

\subsubsection{244-A and 244-S Passive Ventilation Breather Filter Installations.} Installation of passive ventilation breather filter systems on the receiver tank and annulus space shall provide for long-term (minimum 15 year design life) ventilation of the tank.

a. The receiver tank HEPA filter assembly shall be installed on the exhaust fan inlet riser (after removal of the butterfly valve and duct pipe). The annulus HEPA filter assembly shall be installed on an inspection riser above the annulus.

b. The HEPA filter assembly design shall include provisions for installation and operation of a compliant portable exhauster.

c. Each passive HEPA filter assembly shall, at a minimum, consist of a HEPA filter housing, HEPA filter, HEPA filter isolation valve (normally open during operation), seal loop assembly, and seal loop assembly isolation valve (normally open during operation). Other HEPA filter assembly requirements shall be in accordance with released $\mathrm{CH} 2 \mathrm{M}$ HILL design drawings.

d. The HEPA filter isolation valve shall isolate the HEPA filter (from the receiver tank or annulus) to facilitate aerosol testing of the filter, and to isolate a failed filter until the filter can be replaced. The isolation valve shall be manually operated.

e. The seal loop isolation valve shall isolate the seal loop from the ventilation flow path to accommodate seal loop maintenance. 
f. The HEPA filter assembly ducting, isolation valves, and filter housing design shall meet ASME N509 and ASME AG-1 design requirements.

g. HEPA filters shall be procured in accordance with HNF-S-0552 and TFC-ENGSTD-07 to ensure compliance with ASME AG-1 requirements.

h. The primary tank passive ventilation system shall not restrict flow for flammable gas removal, i.e., the breather filter shall accommodate a minimum of $9.0 \mathrm{cfh}$ ( 3.0 cfh per dip tube).

i. All other penetrations and potential flow paths shall be sealed to ensure, to the extent practical, that the ventilation flow is through a HEPA-filtered path.

\subsubsection{296-A-25 and 296-S-22 Stack Electrical, Monitoring Instrumentation,} and Alarm Deactivation. The 296-A-25 and 296-S-22 stack ventilation system electrical, monitoring instrumentation, and alarms shall be disconnected as described below.

a. The power supply to the exhauster fan motor and temperature element shall be disconnected.

b. The power supply to the MOV and the heater in the filter pit shall be disconnected.

c. The power supply to the exhaust stack unit enclosure (i.e, the CAM unit, sample pumps, heat trace, heaters, fan, and local alarm box) shall be disconnected. The CAM, sample pumps and other equipment shall be removed for reuse as identified by Operations.

d. The power supply to the existing HEPA filter banks differential pressure indictors shall be disconnected.

e. The power to the stack drain heat trace shall be disconnected.

f. The power to the annulus inlet filter and temperature element shall be disconnected.

g. The power to the ventilation system alarms in the alarm buildings (e.g., 242-A Evaporator Building for 244-A) shall be disconnected.

Note: "Disconnected" means physical disconnection and removal of wires from the power source.

\subsubsection{244-A and 244-S HEPA Filter Bank Removal and Duct Jumper} Installation in the Filter Pit. The HEPA filter banks in the 244-A and 244-S filter pits shall be removed and a duct jumper installed as described below.

a. Removal and disposition of items shall be controlled per TFC-BSM-FPM-MC-C01, Material Receipt, Storage, Issuance, Return, and Excess Control, Section 4.4

b. The HEPA filter banks and associated jumpers shall be removed and disposed of. 
c. To support receiver tank ventilation, a duct jumper shall be fabricated and installed (to replace the removed HEPA filter banks) between the receiver tank ventilation inlet and outlet nozzles.

d. The ducting jumper shall meet ASME N509 and ASME AG-1 design and testing requirements.

e. A process blank shall be installed on the annulus inlet nozzle to create and airtight seal to ensure that cross-contamination shall not occur between the receiver tank and annulus.

\subsubsection{296-A-25 and 296-S-22 Exhaust Fan and Stack Isolation. The 296-A} 25 and 296-S-25 Exhaust Fans and Stacks shall be isolated as described below.

a. Removal and disposition of items shall be controlled per TFC-BSM-FPM-MC-C01, Material Receipt, Storage, Issuance, Return, and Excess Control, Section 4.4.

b. The expansion joints on the exhaust fan inlet and outlet shall be removed and disposed of.

c. An isolation cap shall be installed on the exhaust fan inlet and outlet, and on the stack inlet (i.e, where the expansion joints were attached).

d. An isolation cap shall be installed on top of the exhaust stack.

e. The isolation caps shall be designed and installed such that water, wind-blown debris, small animals, and insects cannot readily infiltrate.

f. The butterfly valve, temperature element, and ductwork from the ventilation riser to the exhaust shall be removed and disposed of. The receiver tank breather filter assembly will be attached on the riser as discussed in Section 4.3.1.1.

g. The exhaust stack drain line shall be plugged as close to the stack as possible (e.g., at the nearest valve). If feasible, the abandoned drain line, heat trace, and insulation shall be removed and disposed of.

4.3.1.5 244-A and 244-S Annulus Inlet Filter Isolation. The 244-A and 244-S annulus inlet filter assemblies shall be isolated via installation of a blanking plate at the butterfly valve. The annulus inlet filters shall be abandoned in-place.

\subsubsection{6-B-28 and 296-T-18 Stack Isolation Projects}

The following subsections describe the requirements, constraints, and criteria for the 296-B28 (244-BX) and 296-T-18 (244-TX) Stack Isolation Projects.

\subsubsection{244-BX and 244-TX Passive Ventilation Breather Filter Installations.} Installation of passive ventilation breather filter systems on the receiver tank and annulus space shall provide for long-term (minimum 15 year design life) ventilation of the tank. 
a. The receiver tank HEPA filter assembly shall be installed on the exhaust fan inlet riser (after removal of the butterfly valve and duct pipe). The annulus HEPA filter assembly shall be installed on an inspection riser above the annulus.

b. The HEPA filter assembly design shall include provisions for installation and operation of a compliant portable exhauster.

c. The HEPA filter assembly shall, at a minimum, consist of a HEPA filter housing, HEPA filter, HEPA filter isolation valve (normally open during operation), seal loop assembly, and seal loop assembly isolation valve (normally open during operation). Other HEPA filter assembly requirements shall be in accordance with released $\mathrm{CH} 2 \mathrm{M}$ HILL design drawings.

d. The HEPA filter isolation valve shall isolate the HEPA filter (from the receiver tank or annulus) to facilitate aerosol testing of the filter, and to isolate a failed filter until the filter can be replaced. The isolation valve shall be manually operated.

e. The seal loop isolation valve shall isolate the seal loop from the ventilation flow path to accommodate seal loop maintenance.

f. The HEPA filter assembly ducting, isolation valves, and filter housing design shall meet ASME N509 and ASME AG-1 design requirements.

g. HEPA filters shall be procured in accordance with HNF-S-0552 and TFC-ENGSTD-07 to ensure compliance with ASME AG-1 requirements.

h. The primary tank passive ventilation system shall not restrict flow for flammable gas removal, i.e., the breather filter shall accommodate a minimum of $9.0 \mathrm{cfh}(3.0$ cfh per dip tube).

i. All other penetrations and potential flow paths shall be sealed to ensure, to the extent practical, that the ventilation flow is through a HEPA-filtered path.

\subsubsection{296-B-28 and 296-T-18 Stack Electrical, Monitoring Instrumentation,} and Alarm Deactivation. The 296-B-28 and 296-T-18 stack ventilation system electrical, monitoring instrumentation, and alarms shall be disconnected as described below.

a. The power supply to the exhauster fan motor and temperature element shall be disconnected.

b. The power supply to the MOV and the heater in the filter pit shall be disconnected.

c. The power supply to the exhaust stack unit enclosure (i.e, the CAM unit, sample pumps, heat trace, heaters, fan, and local alarm box) shall be disconnected. The CAM, sample pumps and other equipment shall be removed for reuse as identified by Operations.

d. The power supply to the existing HEPA filter banks differential pressure indictors shall be disconnected.

e. The power to the stack drain heat trace shall be disconnected. 
f. The power to the annulus inlet filter and temperature element shall be disconnected.

g. The power to the ventilation system alarms in the alarm buildings (e.g., 244-BX271 and 241-BY-252 for 244-BX) shall be disconnected.

Note: "Disconnected" means physical disconnection and removal of wires from the power source.

4.3.2.3 244-BX and 244-TX HEPA Filter Bank Isolation in the Filter Pit. The HEPA filter banks in the 244-BX and 244-TX filter pits shall be isolated and abandoned in-place as described below.

a. The HEPA filter banks shall be isolated via manually closing the isolation valves upstream and downstream of the HEPA filter banks.

b. The MOV separating the receiver tank and annulus ventilation paths shall be verified as closed. (The power to the MOV is terminated per Section 4.3.2.2)

c. If the MOV cannot be verified as closed, then the MOV or MOV jumper shall be removed and the ventilation pathways from both the receiver tank and annulus isolated with an air-tight seal.

4.3.2.4 296-B-28 and 296-T-18 Exhaust Fan and Stack Isolation. The 296-BX 28 and 296-T-18 Exhaust Fans and Stacks shall be isolated as described below.

a. Removal and disposition of items shall be controlled per TFC-BSM-FPM-MC-C01, Material Receipt, Storage, Issuance, Return, and Excess Control, Section 4.4.

b. The expansion joints on the exhaust fan inlet and outlet shall be removed and disposed of, and replaced with isolation caps (i.e, four places).

c. An isolation cap shall be installed on top of the exhaust stack.

d. The isolation caps shall be designed and installed such that water, wind-blown debris, small animals, and insects cannot readily infiltrate.

e. The exhaust stack drain line shall be plugged as close to the stack as possible (e.g., at the nearest valve). If feasible, the abandoned drain line, heat trace, and insulation shall be removed and disposed of.

4.3.2.5 244-BX and 244-TX Annulus Inlet Filter Isolation. The 244-BX and 244-TX annulus inlet filter assemblies shall be isolated via installation of a blanking plate at the butterfly valve. The annulus inlet filter shall be abandoned in-place.

\subsection{Materials}

The passive HEPA filter assembly duct/pipe, isolation valve, and filter housing(s) shall meet ASME N509 and ASME AG-1 requirements. HEPA filters shall meet HNF-S-0552 \& TFCENG-STD-07 procurement requirements. Other materials used for the new passive ventilation 
system and isolation of the existing system shall follow applicable codes and standards identified in Chapter 3.0.

\subsection{Architectural/Civil Engineering and Site Work}

The FFCA Stack Isolation Project shall be planned to minimize site work. Ground scans will be required before any excavations; however, excavation is not anticipated.

\subsection{Mechanical Engineering}

All modifications to the piping systems shall meet the requirements of ASME B31.3, Process Piping.

\subsection{Electrical, Instrumentation, and Controls}

All electrical modifications shall conform to the site-adopted revision of the National Fire Protection Association (NFPA) 70, National Electric Code. The electrical modifications shall also be approved in accordance with the requirements of the Hanford Electrical Safety Program (HESP).

\subsection{Safety}

Stack isolation project work shall be planned with the intent to minimize environmental releases and work exposure using the As Low As Reasonably Achievable (ALARA) principles. Industrial and occupational safety provisions shall be addressed in specific work packages or facility manuals and procedures.

\subsection{Radiation and Nuclear Control}

Stack isolation work shall be performed using the ALARA principles. All work shall be performed following the applicable radiological controls specified in HNF-5183, Tank Farm Radiological Control Manual. An unreviewed safety question (USQ) evaluation for all work packages (with released ECNs) and procedure revisions shall be conducted.

\subsection{Human Engineering}

Not applicable.

\subsection{Waste Management}

Waste generated during the isolation work shall be disposed of using current site standards as applicable.

\subsection{Project Interfaces}

The interface control document (ICD) for the DST System and the Plutonium Finishing Plant is documented in HNF-4486, Interface Control Document Between The Double-Shell Tank System And The Plutonium Finishing Plant. The ICD for the Tank Farm System and the 222-S Lab is documented in HNF-4483, Interface Control Document Between the Tank Farm System and 
222-S Laboratory. Other project ICDs shall be developed to co-ordinate stack isolation with existing user facilities/organizations and other concurrent projects (e.g. E-525, W-314, and Interim Stabilization), as needed. The Project Organization and Standards Interface is depicted in Figure 4-1.

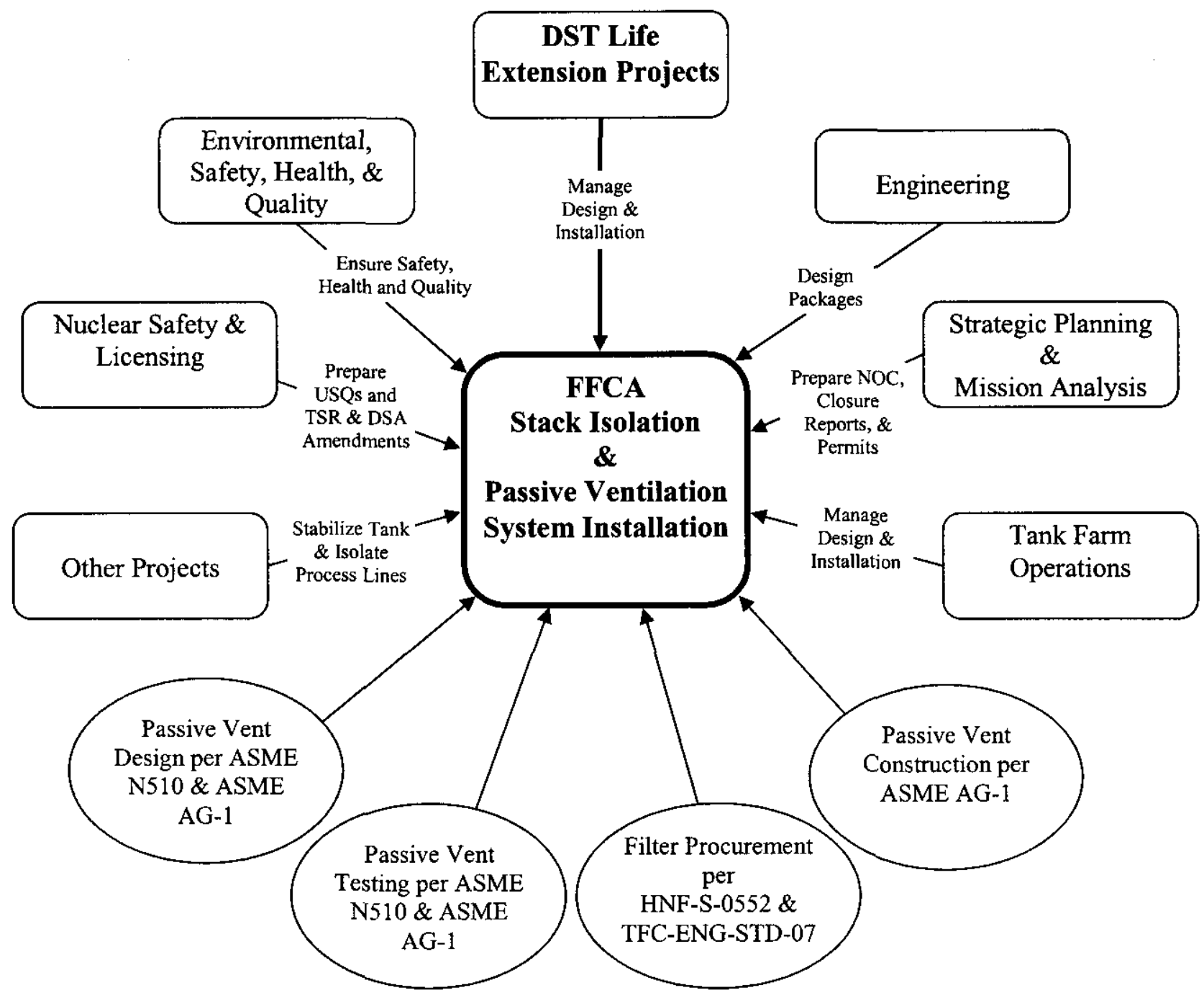

Figure 4-1. FFCA Project Organization and Standards Interface

\subsection{Security}

Stack isolation projects shall not affect the existing security measures as currently provided in the 200 Areas. 


\subsection{Qualification}

Passive HEPA filter ventilation pipe/duct, isolation valves, and filter housings shall be qualified to ASME N510 and ASME AG-1 testing requirements. HEPA filters shall be tested per site procedures.

\subsection{QUALITY ASSURANCE}

Quality assurance program requirements from Title 10, Code of Federal Regulations, Part 830.120 (10 CFR 830.120), Quality Assurance, and the U.S. Department of Energy Order 414.1A, Quality Assurance, form the basis for the CH2M Hill quality assurance program. These requirements are implemented through TFC-PLN-02, Quality Assurance Program Description and TFC-ESHQ-Q ADM-D-04, Quality Assurance Program Description Implementation Matrix. Quality requirements for the Stack Isolation Project are derived from these documents and shall be identified in engineering documents and work packages developed specifically for this effort, or identified in existing documents that will be used as part of this effort.

Procurement and subsequent control of items/components shall be per TFC-BSM-CP-CPR-C-03, and TFC-BSM-FPM-MC-C-01, as appropriate. All items/components shall be procured with documentation appropriate to their identified safety classification and/or other qualification requirements. Quality procurement clauses shall be identified to assure component traceability and vendor qualification requirements.

\subsection{Inspections}

Passive breathing systems shall be inspected under a quality assurance program that meets the requirements of ASME NQA-1.

\subsection{Test and Examinations}

The HEPA ducting, isolation valve and filter housings shall be tested per ASME N510 and ASME AG-1.

\subsection{TURNOVER}

Upon completion of each stack isolation project, turnover to the applicable Facility Operations department shall be in accordance with TFC-PRJ-PM-C-06, Operational Acceptance. Before completion of the isolation activities, an Operational Acceptance Checklist shall be prepared identifying changes to the TSR, DSA, procedures, etc. After changes to the documents are finalized, an Operational Acceptance turnover document shall be prepared and delivered to Operations management.

In addition, at the completion of the stack isolation activities, the EPA shall be notified of compliance with the FFCA. 